\title{
Long-term selection experiment with Afrikaner cattle 2. Genetic parameters and genotype $x$ environment interaction for calf growth traits
}

\author{
L.M. Beffa ${ }^{1,2,3}$, J.B. van Wyk ${ }^{1 \#}$ and G.J. Erasmus ${ }^{1}$ \\ ${ }^{1}$ University of the Free State, P.O. Box 339, Bloemfontein 9300, South Africa \\ ${ }^{2}$ Matopos Research Station, P. Bag K5137, Bulawayo, Zimbabwe
}

\begin{abstract}
A selection and line $\mathrm{x}$ environment interaction study with grade Afrikaner cattle was established in 1956 at Matopos Research Station, Zimbabwe. Two selection lines of 100 cows each were reared in different management environments. The non-supplemented (NS) line relied on the range throughout the year and was mated to calve with the onset of the rains (December to February). The supplemented (S) line was offered protein-rich supplements during the dry season and mated to calve prior to the onset of the rains (October to December). In 1976, lines were sub-divided into 75 cows each, where one sub-line remained within each environment as a control; the remaining sub-lines were interchanged between environments. Bulls were selected on weaning weight within control lines, while replacement heifers were selected on weight at mating within sub-line. Data recorded over approximately six generations of selection (40 years) was analyzed. The direct heritability estimates were moderate for birth weight (0.4), but low (0.1 to 0.2$)$ for the other traits, similarly maternal heritabilities were low (0.1 to 0.2$)$. Permanent environmental effects due to dam were moderate (0.3) for weights at 205 days, weaning and at 12 months, and was still an important effect at 18 months. Relatively large negative (-0.4) direct-maternal genetic correlations were indicated for weaning and yearling weights. There were indications that all post-weaning weight traits evaluated were closely related giving rise to their joint inclusion in joint multivariate analysis. There were no indications of line $\mathrm{x}$ environment interactions, however, interaction of sire $\mathrm{x}$ year was important for all the traits highlighting the tremendous year to year variations experienced in the sub-tropics. There is a need to evaluate selection for genotypic stability, particularly for the more extensive farming environments.
\end{abstract}

\footnotetext{
Keywords: Sanga, beef cattle, sub-tropics, direct heritability, maternal effects, correlations

${ }^{\#}$ Corresponding author. E-mail: vanwykjb.sci@ufs.ac.za

${ }^{3}$ Current address: Livestock Identification Trust, P.O. Box BE 209, Belvedere, Harare, Zimbabwe
}

\section{Introduction}

Accurate estimates of genetic parameters are essential for the design and implementation of efficient genetic improvement programmes. There are numerous genetic parameter estimates for Bos taurus and $B$. indicus breeds in temperate and tropical environments (review Koots et al., 1994). However, estimates for Sanga cattle in sub-tropical environments are scarce, particularly from reasonably large data sets using the current commonly adopted mixed model and REML (restricted maximum likelihood) procedures described by Henderson (1984).

Estimates of variances and covariances of cattle in the tropics and sub-tropics have, in general, been similar to those in temperate environments (Groeneveld et al., 1998). Some studies have, however, reported differences between these regions (Hetzel et al., 1990), and Meyer (1994) reported that the genetic determinants of growth at various ages were more diverse in the tropics. The large year-to-year and within season environmental variation experienced in the sub-tropics (mainly as a result of variable quantity and distribution of rainfall) may give rise to 'random' sire x year interactions (Notter \& Hohenboken, 1990), posing additional difficulties in the identification and selection of superior individuals to be parents for future production (Vercoe \& Frisch, 1992). Mathur (2002) advocated the multivariate approach to estimate the genetic correlation for each pair of environments to evaluate the significance of the interactions on breeding programmes. The focus of this study was to estimate genetic parameters and determine the presence of a line 
$\mathrm{x}$ environment interaction for calf growth traits between birth and 18 months of age of Afrikaner cattle (Bos taurus africanus) in a sub-tropical environment.

\section{Materials and Methods}

The animals, environment, experimental protocol, calf growth traits and development of fixed effect models have been described in a companion paper (Beffa et al., 2009). Briefly, the experiment was carried out in the sub-tropical environment of Matopos Research Station, Zimbabwe. Two lines of 100 grade Afrikaner cows each were established in 1956 and subjected to different nutritional and management regimes. The supplemented line cows were offered supplements during the dry season and mated to calve early (October to December) relative to the expected onset of the rains. The non-supplemented line cows were mated to calve two months later than those in the supplemented line. A fixed mating season of 90 days and four single-sired herds of 25 cows each were used within each line. Selection for weight within line, to establish lines adapted to their respective environments, was based on weight at weaning for bulls and weight prior to mating (three years) for replacement heifers. In 1976 the number of breeding females in each line was increased to 150 and two equal sub-lines were created. One sub-line remained within each environment as a control; the remaining sub-lines were interchanged between environments. Bulls were selected within the control sub-lines and were used within line across environments. Cows were mated in five single-sire herds of 15 cows each. Four bulls were replaced each year and one was retained as a repeat sire. The data analyzed in this study was collected over 40 years (1958 to 1997).

Weights at birth (BW), 205 days (W205), weaning (WW), 12 (W12) and 18 months (W18) and postweaning gain (PWG) were analyzed. In order to account for all interactions with year of birth, a concatenation of line-year-environment classification was employed. For all the traits, only two classes of sex were considered. Pre-weaning, these were intact males versus females and post-weaning, these were steers versus heifers. Similarly, in order to account for the interaction as well as confounding of heifer with previous lactation status (PLS), a class model concatenating three classes for PLS (three year old heifers; cows not suckling in the previous season; and cows that had suckled a calf at least up to and until the calf had attained 90 days of age) with five age of dam classes (3, 4, 5 to 7,8 to 10 and $>10$ years of age) was employed. The effects of birth date were accounted for by its inclusion as a cross-classified covariate regressed from the year-environment subclass means. A sequence of 5 random models was fitted using ASREML (Gilmour et al., 2002). Model 1 (M1) included only direct genetic effects. Because the aim of the long-term selection experiment was to examine a genotype $\mathrm{x}$ environmental effect, a sire $\mathrm{x}$ year effect was added as another random component in Model 2 (M2). Model 3 (M3) added the maternal genetic effect to the terms in M2 and permanent maternal environmental effect to terms in M3 was added to Model 4 (M4). Model 5 (M5) added the covariance between direct and maternal genetic effects to M4.

The full model in matrix notation is shown below:

$$
\mathrm{Y}=\mathrm{X} \beta+\mathrm{Z}_{1} \mathrm{a}+\mathrm{Z}_{2} \mathrm{sy}+\mathrm{Z}_{3} \mathrm{~m}+\mathrm{Z}_{4} \mathrm{c}+\varepsilon, \quad \operatorname{cov}(\mathrm{a}, \mathrm{m})=\mathrm{A} \sigma_{\mathrm{am}}
$$

where: $\mathrm{Y}$ is the vector of observations;

$\beta$ is the vector of fixed effects;

$\mathrm{X}$ is the incidence matrix that associates $\beta$ with $\mathrm{Y}$;

$\mathrm{a}$ is the vector of breeding values for direct genetic effects;

sy is the vector of breeding values for sire $\mathrm{x}$ year effects;

$\mathrm{m}$ is the vector of breeding values for maternal genetic effects;

$\mathrm{c}$ is the vector of permanent environmental effects due to dam;

$\mathrm{Z}_{1}, \mathrm{Z}_{2}, \mathrm{Z}_{3}$ and $\mathrm{Z}_{4}$ are the incidence matrices that associate $\mathrm{a}, \mathrm{m}$, sy and $\mathrm{c}$ with $\mathrm{Y}$; and $\varepsilon$ is the vector of residual effects.

Furthermore, with A, the numerator relationship matrix between animals, $\mathrm{I}_{\mathrm{n}}$, an identity matrix with order $\mathrm{n}$, the number of dams, $\mathrm{I}_{\mathrm{s}}$, an identity matrix with order $\mathrm{s}$, the number of sire $\mathrm{x}$ year classes and $\mathrm{I}$, an identity matrix with order of the number of records. The (co)variance structure of random effects can be described as: $\mathrm{V}(\mathrm{a})=\sigma_{\mathrm{a}}^{2} \mathrm{~A}, \mathrm{~V}(\mathrm{~m})=\sigma_{\mathrm{m}}^{2} \mathrm{~A}, \mathrm{~V}(\mathrm{sy})=\sigma_{\mathrm{sy}}^{2} \mathrm{I}_{\mathrm{s}}, \mathrm{V}(\mathrm{c})=\sigma_{\mathrm{c}}^{2} \mathrm{I}_{\mathrm{n}}, \mathrm{V}(\varepsilon)=\sigma_{\varepsilon}^{2} \mathrm{I}$, where $\sigma_{\mathrm{a}}^{2}$ is the direct genetic variance; $\sigma_{\text {sy }}^{2}$ is the sire $x$ year variance, $\sigma_{m}^{2}$ is the maternal genetic variance; $\sigma_{c}^{2}$ is the maternal 
permanent environment variance; $\sigma_{\mathrm{e}}^{2}$ is the residual variance and $\sigma_{\mathrm{am}}$ is the genetic covariance between direct and maternal effects. There were a total of 7175 animals in the pedigree file that included 254 base animals. Tests of significance for each random effect were performed using the log likelihood ratio (LR) test after inclusion of an extra random effect (excluding the residual) to the fixed effects model. An effect was considered significant when its inclusion in the model caused a significant increase in the log likelihood ratio. A chi square distribution for $\alpha=0.05$ and one degree of freedom was used as the critical test statistic (3.841). When -2 times the difference between log likelihoods was greater than the critical value the inclusion of the effect was considered significant. Models and estimates obtained from the most appropriate single-trait analyses were used as starting values in multi-trait analyses, initiating with bi-variate analysis with the intention of building a five-trait model.

The presence of genotype $\mathrm{x}$ environment interactions for the five growth traits were determined by genetic correlation estimates of the trait treated as different traits in each of the two environments, where only the post-crossover (1977 to 1997) data were considered that only included parameters indicated from most appropriate single trait analyses with the complete data set.

\section{Results and Discussion}

A total of 214 sires and 1578 dams had progeny records across the data set. According to the LR test from single-trait analyses the most appropriate model for the growth traits included direct and maternal genetic effects and sire $\mathrm{x}$ year effects (Table 1). Permanent environmental effects due to the dam were not important for BW and PWG, while the inclusion of the covariance between direct and maternal genetic effects was indicated for WW and W12. The direct heritabilities $\left(\mathrm{h}^{2}{ }_{\mathrm{a}}\right)$ were moderate $(0.4)$ for $\mathrm{BW}$, but low ( 0.1 to 0.2$)$ for the other traits (Table 2). Similarly, the maternal heritabilities $\left(\mathrm{h}^{2}{ }_{\mathrm{m}}\right)$ were low $(0.1$ to 0.2$)$, being highest for WW and W12. The interaction of sire $\mathrm{x}$ year was important for all the traits, only accounting for $<4 \%$ of the total variation. Permanent environmental effects due to dam were moderate $(0.3)$ for W205, WW and W12, and were still an important effect at 18 months. Relatively large negative directmaternal genetic correlations were indicated for WW and W12.

Groeneveld et al. (1998) and Mostert et al. (1998) report on parameters obtained from a four-trait model used to analyze field data of Afrikaner weights from the National Beef Performance Testing Scheme in South Africa (which did not include possible interactions with sire effects). Direct heritabilities were higher for BW, WW and YW $(0.52,0.23$ and 0.17 , respectively), but similar for W18 (0.17), while all maternal heritabilities were lower $(0.03$ to 0.10$)$ and consistently large and negative (-0.5) direct-maternal correlations were shown for all the traits. The inclusion of the sire $\mathrm{x}$ year interaction term has been reported to reduce both the direct heritability and the direct-maternal correlation estimates (Robinson, 1994; 1996; Neser et al., 1996; Meyer, 1997; Berweger Baschnagel et al., 1999; Maniatis \& Pollott, 2002; Meyer, 2003).

The presence of maternal effects for post-weaning traits has been ascribed to a part-whole relationship between pre- and post-weaning traits (Meyer, 1992; 1994). Meyer (1997) notes that the estimation of maternal effects and corresponding genetic parameters are problematic, because the direct and maternal effects are generally confounded, expression of maternal effects is sex limited, occurs late in the life of a female and lags by one generation. Numerous studies have reported large negative direct-maternal correlation and while a weak adverse relationship has been considered plausible, strong negative ones have been viewed with scepticism (Meyer, 1997). The large negative correlations could be due to other sources of variation, e.g. sire x year interactions (Robinson, 1996; Meyer, 1997; Eler et al., 1998) and failure to account for sources of variation such as paddocks or management groups which inflate the variance between paternal half sibs in a contemporary group (Meyer, 1997).

Hetzel et al. (1990) also found negligible permanent environment effects for BW and sizeable effects for pre-weaning traits for cattle breeds in the Australian tropics. In the analysis of large Australian beef field data sets Meyer (2002) reported that maternal effects $\left(\mathrm{h}_{\mathrm{m}}^{2}\right.$ and $\left.\mathrm{c}^{2}\right)$ gradually decreased with increasing calf age, but were still important at 700 days. In contrast, Pereira et al. (2008) reported negligible maternal effects $(0.01+0.04)$ in their analysis of data from a herd of Creole cattle in the tropics of Brazil.

Convergence of multivariate models with any combination of W205, WW, W12 or W18 was problematic due to direct genetic correlation estimates approaching unity, suggesting all four post-birth weight traits were genetically very similar (data not shown). Furthermore maternal heritability estimates were grossly inflated relative to the univariate estimates. Parameter estimates from three-trait multivariate 
models with BW, PWG and one of post-birth weight traits were either the same or slightly greater $(\mathrm{P} \leq 0.05)$ than the univariate models, especially for maternal traits (Table 3). Direct genetic correlations of BW declined from 0.8 with W205 to 0.2 with PWG, while maternal genetic correlations with BW were all low (0.2 to 0.4). Direct correlation estimates of post-birth weight traits with PWG was lowest for WW (0.5), higher for W205 and W12 (0.7) and close to unity for W18, while maternal estimates decreased from -0.5 to -0.3 as calf age increased. The direct genetic and maternal genetic correlations (Table 4) were similar to the estimates reported by Groeneveld et al. (1998) and Mostert et al. (1998), who also noted the very high direct genetic correlation between WW and YW, noting these two traits were closely related. Groeneveld et al. (1998) also noted that herd-year-season (HYS) classification resulted in an over-parameterized model (many sub-classes with few observations) resulting in dependencies. In order to overcome these dependencies while accounting for their importance, HYS was included as a random effect.

Table 1 Log likelihood ratios (LR) obtained from single-trait analyses fitting different random effect models with the 'best' model in bold; critical value of $\chi^{2}$ with $1 \mathrm{df}=3.84$

\begin{tabular}{|c|c|c|c|c|}
\hline Trait & Model $^{1}$ & Parameters in model ${ }^{1}$ & LR & $-2 x \operatorname{diff} \log L$ \\
\hline \multirow[t]{5}{*}{ Birth weight } & 1 & $\mathrm{~h}^{2}$ & -2634.7 & \\
\hline & 2 & $\mathrm{~h}^{2}+\mathrm{c}_{\mathrm{sy}}^{2}$ & -2628.5 & 12.4 \\
\hline & 3 & $\mathbf{h}^{2}+\mathbf{c}_{\mathrm{sy}}^{2}+\mathbf{m}^{2}$ & -2560.6 & 135.8 \\
\hline & 4 & $\mathrm{~h}^{2}+\mathrm{c}_{\mathrm{sy}}^{2}+\mathrm{m}^{2}+\mathrm{c}_{\mathrm{pe}}^{2}$ & -2560.4 & 0.4 \\
\hline & 5 & $\mathrm{~h}^{2}+\mathrm{c}_{\mathrm{sy}}^{2}+\mathrm{m}^{2}+\mathrm{c}_{\mathrm{pe}}^{2}+\mathrm{r}_{\mathrm{am}}$ & -2558.9 & 3.0 \\
\hline \multirow[t]{5}{*}{ 205-day weight } & 1 & $\mathrm{~h}^{2}$ & -1984.4 & \\
\hline & 2 & $\mathrm{~h}^{2}+\mathrm{c}_{\mathrm{sy}}^{2}$ & -1963.7 & 20.7 \\
\hline & 3 & $\mathrm{~h}^{2}+\mathrm{c}_{\mathrm{sy}}^{2 \mathrm{y}}+\mathrm{m}^{2}$ & -1525.8 & 875.8 \\
\hline & 4 & $h^{2}+c_{s y}^{2}+m^{2}+c_{p e}^{2}$ & -1474.8 & 102.0 \\
\hline & 5 & $h^{2}+c_{s y}^{2}+m^{2}+c_{p e}^{2}+r_{a m}$ & -1473.6 & 2.4 \\
\hline \multirow[t]{5}{*}{ Weaning weight } & 1 & $\mathrm{~h}^{2}$ & -2206.0 & \\
\hline & 2 & $\mathrm{~h}^{2}+\mathrm{c}_{\mathrm{sy}}^{2}$ & -2186.9 & 38.1 \\
\hline & 3 & $\mathrm{~h}^{2}+\mathrm{c}_{\mathrm{sy}}^{2}+\mathrm{m}^{2}$ & -1633.9 & 1106.1 \\
\hline & 4 & $\mathrm{~h}^{2}+\mathrm{c}_{\mathrm{sy}}^{2}+\mathrm{m}^{2}+\mathrm{c}_{\mathrm{pe}}^{2}$ & -1574.3 & 119.2 \\
\hline & 5 & $h^{2}+c_{s y}^{2}+m^{2}+c_{p e}^{2}+r_{a m}$ & -1571.5 & 5.48 \\
\hline \multirow[t]{5}{*}{ 12-month weight } & 1 & $\mathrm{~h}^{2}$ & -809.5 & \\
\hline & 2 & $h^{2}+c_{s y}^{2}$ & -791.2 & 36.6 \\
\hline & 3 & $h^{2}+c_{s y}^{2}+m^{2}$ & -335.8 & 910.8 \\
\hline & 4 & $\mathrm{~h}^{2}+\mathrm{c}_{\mathrm{sy}}^{2}+\mathrm{m}^{2}+\mathrm{c}_{\mathrm{pe}}^{2}$ & -288.6 & 94.4 \\
\hline & 5 & $h^{2}+c_{s y}^{2}+m^{2}+c_{p e}^{2}+r_{a m}$ & -285.3 & 6.6 \\
\hline \multirow[t]{5}{*}{ 18-month weight } & 1 & $\mathrm{~h}^{2}$ & -9872.9 & \\
\hline & 2 & $h^{2}+c_{s y}^{2}$ & -9861.5 & 22.8 \\
\hline & 3 & $\mathrm{~h}^{2}+\mathrm{c}_{\mathrm{sy}}^{2 \mathrm{y}}+\mathrm{m}^{2}$ & -9737.8 & 247.4 \\
\hline & 4 & $\mathbf{h}^{2}+\mathbf{c}_{\mathrm{sy}}^{2}+\mathbf{m}^{2}+\mathbf{c}_{\mathrm{pe}}^{2}$ & -9716.7 & 42.2 \\
\hline & 5 & $\mathrm{~h}^{2}+\mathrm{c}_{\mathrm{sy}}^{2}+\mathrm{m}^{2}+\mathrm{c}_{\mathrm{pe}}^{2}+\mathrm{r}_{\mathrm{am}}$ & -9716.4 & 0.6 \\
\hline \multirow[t]{5}{*}{ Post-weaning gain } & 1 & $h^{2}$ & -3186.6 & \\
\hline & 2 & $h^{2}+c_{s y}^{2}$ & -3182.3 & 8.6 \\
\hline & 3 & $\mathbf{h}^{2}+\mathbf{c}_{\mathrm{sy}}^{2}+\mathbf{m}^{2}$ & -3169.3 & 26.0 \\
\hline & 4 & $\mathrm{~h}^{2}+\mathrm{c}_{\mathrm{sy}}^{2}+\mathrm{m}^{2}+\mathrm{c}_{\mathrm{pe}}^{2}$ & -3169.3 & 0.0 \\
\hline & 5 & $\mathrm{~h}^{2}+\mathrm{c}_{\mathrm{sy}}^{2}+\mathrm{m}^{2}+\mathrm{c}_{\mathrm{pe}}^{2}+\mathrm{r}_{\mathrm{am}}$ & -3169.2 & 0.2 \\
\hline
\end{tabular}

${ }^{1}$ Direct genetic $\left(\mathrm{h}^{2}\right)$; sire $\mathrm{x}$ year $\left(\mathrm{c}^{2}{ }_{\mathrm{sy}}\right)$; maternal genetic $\left(\mathrm{m}^{2}\right)$; permanent environmental $\left(\mathrm{c}^{2}{ }_{\mathrm{pe}}\right)$; direct-maternal genetic correlation $\left(\mathrm{r}_{\mathrm{am}}\right)$. 
Table 2 Estimates of (co)variance components and ratios from the single-trait ${ }^{1}$ analyses

\begin{tabular}{lcccccc}
\hline Variance Components: & BW & W205 & WW & W12 & W18 & PWG \\
\hline Total phenotypic & 19.92 & 441.0 & 480.5 & 573.8 & 729.1 & 5439 \\
Residual & 9.15 & 209.5 & 196.6 & 226.3 & 371.6 & 3901 \\
Direct additive & 7.68 & 31.4 & 56.6 & 62.0 & 144.6 & 1055 \\
Maternal additive & 2.93 & 62.7 & 96.3 & 127.5 & 82.7 & 353 \\
Sire x year interaction & 0.16 & 12.5 & 11.5 & 13.3 & 25.8 & 123 \\
Permanent environmental & - & 123.7 & 150.7 & 144.8 & 104.5 & - \\
$\quad$ Direct-maternal covariance & - & - & -31.3 & -41.2 & - & - \\
Variance Ratios: & & & & & & \\
$\quad$ Direct heritability & 0.38 & 0.07 & 0.12 & 0.11 & 0.20 & 0.20 \\
$\quad($ s.e. $)$ & $(0.04)$ & $(0.02)$ & $(0.03)$ & $(0.03)$ & $(0.04)$ & $(0.04)$ \\
Maternal heritability & 0.15 & 0.14 & 0.20 & 0.22 & 0.11 & 0.07 \\
$\quad$ s.e.) & $(0.02)$ & $(0.03)$ & $(0.04)$ & $(0.04)$ & $(0.03)$ & $(0.02)$ \\
Sire x year & 0.01 & 0.03 & 0.02 & 0.02 & 0.04 & 0.02 \\
$\quad$ s.e.) & $(0.01)$ & $(0.01)$ & $(0.01)$ & $(0.01)$ & $(0.01)$ & $(0.01)$ \\
$\quad$ Dam permanent environment & - & 0.28 & 0.31 & 0.25 & 0.14 & - \\
$\quad(s . e)$. & - & $(0.03)$ & $(0.03)$ & $(0.03)$ & $(0.02)$ & - \\
Direct-maternal correlation & - & - & -0.42 & -0.46 & - & - \\
$\quad$ (s.e.) & - & - & $(0.13)$ & $(0.12)$ & & - \\
\hline
\end{tabular}

${ }^{1}$ Weights at birth (BW); 205 days (W205); weaning (WW); 12 (W12) and 18 (W18) months; post-weaning gain (PWG).

Table 3 Estimates of variance components and ratios obtained from three-trait ${ }^{1}$ analyses

\begin{tabular}{|c|c|c|c|c|c|c|c|c|}
\hline $\begin{array}{l}\text { Parameters for trait: } \\
\text { Traits included in analysis: }\end{array}$ & $\begin{aligned} & \underline{\mathbf{B W}} \\
&+\mathrm{W} 205 \\
&+\mathrm{PWG}\end{aligned}$ & $\begin{array}{c}\frac{\mathbf{B W}}{+\mathrm{WW}} \\
+\mathrm{PWG}\end{array}$ & $\begin{array}{l}\frac{\mathrm{W} 205}{+\mathrm{BW}} \\
+\mathrm{PWG} \\
\end{array}$ & $\begin{array}{c}\frac{\mathbf{W W}}{+\mathrm{BW}} \\
+\mathrm{PWG}\end{array}$ & $\begin{array}{c}\frac{\mathbf{W 1 2}}{+\mathrm{BW}} \\
+\mathrm{PWG}\end{array}$ & $\begin{array}{r}\frac{\mathbf{W 1 8}}{+\mathrm{BW}} \\
+\mathrm{PWG} \\
\end{array}$ & $\begin{array}{c}\frac{\mathbf{P W G}}{+\mathrm{BW}} \\
+\mathrm{W} 205\end{array}$ & $\begin{array}{l}\frac{\text { PWG }}{+\mathrm{BW}} \\
+\mathrm{WW} \\
\end{array}$ \\
\hline \multicolumn{9}{|l|}{ Variance components: } \\
\hline Total phenotypic & 18.72 & 19.67 & 461.4 & 527.3 & 590.9 & 752.6 & 5465 & 5470 \\
\hline Residual & 8.59 & 9.29 & 213.1 & 192.6 & 227.8 & 353.5 & 3895 & 3892 \\
\hline Direct additive & 7.32 & 7.31 & 45.3 & 69.8 & 62.8 & 173.4 & 1045 & 1060 \\
\hline Maternal additive & 2.63 & 2.87 & 88.6 & 132.7 & 130.7 & 87.4 & 390 & 390 \\
\hline Sire $\mathrm{x}$ year interaction & 0.18 & 0.19 & 11.4 & 9.2 & 12.2 & 19.9 & 136 & 128 \\
\hline Permanent environmental & - & - & 103.1 & 123.1 & 117.1 & 118.4 & - & - \\
\hline Direct-maternal covariance & - & - & - & -29.3 & -40.6 & - & - & - \\
\hline \multicolumn{9}{|l|}{ Variance ratios: } \\
\hline $\begin{array}{l}\text { Direct heritability } \\
\text { (s.e.) }\end{array}$ & $\begin{array}{c}0.39 \\
(0.04)\end{array}$ & $\begin{array}{c}0.37 \\
(0.04)\end{array}$ & $\begin{array}{c}0.10 \\
(0.02)\end{array}$ & $\begin{array}{c}0.13 \\
(0.03)\end{array}$ & $\begin{array}{c}0.13 \\
(0.03)\end{array}$ & $\begin{array}{c}0.23 \\
(0.04)\end{array}$ & $\begin{array}{c}0.19 \\
(0.04)\end{array}$ & $\begin{array}{r}0.19 \\
(0.04)\end{array}$ \\
\hline $\begin{array}{l}\text { Maternal heritability } \\
\text { (s.e.) }\end{array}$ & $\begin{array}{c}0.14 \\
(0.02)\end{array}$ & $\begin{array}{c}0.15 \\
(0.02)\end{array}$ & $\begin{array}{c}0.19 \\
(0.03)\end{array}$ & $\begin{array}{c}0.25 \\
(0.04)\end{array}$ & $\begin{array}{c}0.28 \\
(0.04)\end{array}$ & $\begin{array}{c}0.12 \\
(0.03)\end{array}$ & $\begin{array}{c}0.07 \\
(0.02)\end{array}$ & $\begin{array}{c}0.07 \\
(0.02)\end{array}$ \\
\hline $\begin{array}{l}\text { Sire x year } \\
\text { (s.e.) }\end{array}$ & $\begin{array}{c}0.01 \\
(0.01)\end{array}$ & $\begin{array}{c}0.01 \\
(0.01)\end{array}$ & $\begin{array}{c}0.03 \\
(0.01)\end{array}$ & $\begin{array}{c}0.02 \\
(0.01)\end{array}$ & $\begin{array}{c}0.02 \\
(0.01)\end{array}$ & $\begin{array}{c}0.03 \\
(0.01)\end{array}$ & $\begin{array}{c}0.03 \\
(0.01)\end{array}$ & $\begin{array}{c}0.02 \\
(0.01)\end{array}$ \\
\hline $\begin{array}{l}\text { Dam permanent environment } \\
\text { (s.e.) }\end{array}$ & - & - & $\begin{array}{c}0.22 \\
(0.02)\end{array}$ & $\begin{array}{c}0.23 \\
(0.03)\end{array}$ & $\begin{array}{c}0.19 \\
(0.03)\end{array}$ & $\begin{array}{c}0.15 \\
(0.02)\end{array}$ & $\begin{array}{l}- \\
-\end{array}$ & $\begin{array}{l}- \\
-\end{array}$ \\
\hline $\begin{array}{l}\text { Direct-maternal correlation } \\
\text { (s.e.) }\end{array}$ & - & $\begin{array}{l}- \\
-\end{array}$ & $\begin{array}{l}- \\
-\end{array}$ & $\begin{array}{l}-0.31 \\
(0.10)\end{array}$ & $\begin{array}{l}-0.36 \\
(0.11)\end{array}$ & $\begin{array}{l}- \\
-\end{array}$ & $\begin{array}{l}- \\
-\end{array}$ & $\begin{array}{l}- \\
-\end{array}$ \\
\hline
\end{tabular}

\footnotetext{
${ }^{1}$ Weights at birth (BW); 205 days (W205); weaning (WW); 12 (W12); 18 (W18) months; post-weaning gain (PWG).
} 
Table 4 Estimates of (co)variance ratios ${ }^{1}(\mathrm{x} 100)$ obtained from three-trait analyses ${ }^{2}$

\begin{tabular}{|c|c|c|c|c|c|c|c|c|c|c|c|c|}
\hline & \multirow[b]{2}{*}{ BW } & \multicolumn{5}{|c|}{ Direct Genetic } & \multicolumn{6}{|c|}{ Maternal Genetic } \\
\hline & & W205 & WW & W12 & W18 & PWG & BW & W205 & $\mathrm{WW}$ & W12 & W18 & PWG \\
\hline BW & $39 \pm 4$ & $78 \pm 8$ & & & & $22 \pm 10$ & $14 \pm 2$ & $53 \pm 8$ & & & & $18 \pm 11$ \\
\hline BW & $37 \pm 4$ & & $61 \pm 8$ & & & $18 \pm 0$ & $15 \pm 2$ & & $47 \pm 8$ & & & $20 \pm 11$ \\
\hline BW & $39 \pm 4$ & & & $61 \pm 9$ & & $19 \pm 10$ & $14 \pm 2$ & & & $37 \pm 8$ & & $22 \pm 11$ \\
\hline $\mathrm{BW}$ & $38 \pm 4$ & & & & $45 \pm 8$ & $19 \pm 10$ & $14 \pm 2$ & & & & $54 \pm 10$ & $22 \pm 11$ \\
\hline W205 & & $10 \pm 2$ & & & & $70 \pm 13$ & & $19 \pm 3$ & & & & $-49 \pm 12$ \\
\hline WW & & & $13 \pm 3$ & & & $50 \pm 2$ & & & $25 \pm 3$ & & & $-45 \pm 10$ \\
\hline W12 & & & & $11 \pm 3$ & & $65 \pm 12$ & & & & $24 \pm 3$ & & $-62 \pm 11$ \\
\hline W18 & & & & & $23 \pm 4$ & $91 \pm 4$ & & & & & $12 \pm 3$ & $-32 \pm 17$ \\
\hline PWG & & & & & & $19 \pm 4$ & & & & & & $7 \pm 2$ \\
\hline PWG & & & & & & $19 \pm 4$ & & & & & & $7 \pm 2$ \\
\hline PWG & & & & & & $20 \pm 4$ & & & & & & $7 \pm 2$ \\
\hline PWG & & & & & & $20 \pm 4$ & & & & & & $7 \pm 2$ \\
\hline
\end{tabular}

Heritabilities on the diagonal (in bold), direct genetic correlations above.

${ }^{2}$ Weights at birth (BW); 205 days (W205); weaning (WW); 12 (W12) and 18 (W18) months; post-weaning gain (PWG).

Table 5 Direct and maternal genetic correlations ( \pm s.e.) for growth traits treated as different traits across environments (1977 to 1997)

\begin{tabular}{lcc}
\hline Trait & Direct genetic & Maternal genetic \\
\hline Birth weight & $0.99 \pm 0.00$ & $0.85 \pm 0.22$ \\
205-day weight & $0.96 \pm 0.00$ & $0.92 \pm 0.30$ \\
Weaning weight & $1.00 \pm 0.00$ & $0.70 \pm 0.30$ \\
12-month weight & $0.98 \pm 0.00$ & $0.90 \pm 0.19$ \\
18-month weight & $0.99 \pm 0.08$ & $0.86 \pm 0.21$ \\
Post-weaning gain & $0.99 \pm 0.08$ & $0.86 \pm 0.21$ \\
\hline
\end{tabular}


The direct genetic and maternal genetic correlation estimates for the weight traits treated as different traits across environments were high (Table 5), and in many instances close to unity, indicative that line $\mathrm{x}$ environment interactions were not important. In pair-wise across country (Argentina, Canada, Uruguay and United States) genetic evaluations of growth in Hereford cattle, Lee \& Bertrand (2002) reported direct and maternal correlations generally greater than 0.8 . These authors concluded that while sires generally rank the same for both direct and maternal genetic performance for pre- and post-weaning growth traits, adjusting for heterogeneous variances was recommended. However, in their analysis of 205-day weights of Nelore calves across four widely different regions in Brazil, Souza et al. (1998) reported low genetic correlations. Spearman correlation coefficients of breeding values confirmed the presence of significant sire $\mathrm{x}$ environment interactions. The significant sire $\mathrm{x}$ year interactions found in the current study warrant further investigation including the need to consider selection for genotypic stability.

\section{Conclusions}

The direct genetic parameter estimates were lower than literature estimates, possibly due to the presence of sire $\mathrm{x}$ year interactions. Meanwhile, maternal parameter estimates were similar to literature estimates and persisted post-weaning. Post-birth weight traits were closely related to each other yielding problems in multivariate data analysis. These factors indicate the need for caution in model building and use of literature estimates to predict performance of Afrikaner cattle in sub-tropical environments. Given the significant sire $\mathrm{x}$ year interactions found for all the growth traits, reflecting the tremendous seasonal differences experienced in the sub-tropics, warrants the evaluation of selection for genotypic stability, particularly for the more extensive farming environments.

\section{Acknowledgements}

This study formed part of the first author's doctorate thesis who benefited from funding from the John Wakeford Scholarship Trust, the Afrikaner Cattle Society of South Africa, the International Livestock Research Institute the South African National Research Foundation and the Livestock Identification Trust. This work was funded by and carried out at Matopos Research Station, Ministry of Agriculture, Zimbabwe.

\section{References}

Beffa, L.M., Van Wyk, J.B. \& Erasmus, G.J., 2009. Long-term selection experiment with Afrikaner cattle. 1. Environmental factors affecting calf growth. S. Afr. J. Anim. Sci. 39, 89-97.

Berweger Baschnagel, M., Moll, J. \& Künzi, N., 1999. Comparison of models to estimate maternal effects for weaning weight of Swiss Angus cattle fitting a sire $\mathrm{x}$ herd interaction as an additional random effect. Livest. Prod. Sci. 60, 203-208.

Eler, J.P., Ferraz, J.B.S, Golden, B.L. \& Silva, P.R., 1998. Effect of sire x herd interactions in estimation of (co)variance components in Nelore cattle. Proc. $6^{\text {th }}$ World Congr. Genet. Appl. Livest. Prod. 26, 165-168.

Falconer, D.S. \& MacKay, T.F.C., 1996. Introduction to Quantitative Genetics. $4^{\text {rd }}$ ed., Longman, Essex, UK.

Gilmour, A.R., Gogel, B.J., Cullis, B.R., Welham, S.J. \& Thompson, R., 2002. ASREML User Guide Release 1.0. VSN International Ltd, Hemel Hempstead, HP11es, UK.

Groeneveld, E., Mostert, B.E. \& Rust, T., 1998. The covariance structure of growth traits in the Afrikaner beef population. Livest. Prod. Sci. 55, 99-107.

Henderson, C.R., 1984. Applications of Linear Models in Animal Breeding. University of Guelph, Ontario, Canada.

Hetzel, D.J.S., Quaas, R.L., Seifert, G.W., Bean, K.G., Burrow, H.M. \& Aspden, W.J., 1990. Genetic parameters for growth of tropical beef cattle. Proc. Aust. Assoc. Anim. Breed. Genet. 8, 517-520.

Johnson, D.L. \& Thompson, R., 1995. Restricted maximum likelihood estimates of variance components for univariate animal models using sparse matrix techniques and average information. J. Dairy Sci. 78, 449-456.

Koots, K.R., Gibson, J.P., Smith, C. \& Wilton, J.W., 1994. Analyses of published genetic parameter estimates for beef production traits. 1. Heritability. Anim. Breed. Abstr. 62, 309-338.

Lee, D.H. \& Bertrand, J.K., 2002. Investigation of genotype x country interactions for growth traits in beef cattle. J. Anim. Sci. 80, 330-337. 
Maniatis, N. \& Pollott, G.E., 2002. Genotype-by-environment interactions in lamb weight and composition traits. Anim. Sci. 75, 3-14.

Mathur, P.K., 2002. Methods for estimation and use of genotype-environment interactions. Proc. $7^{\text {th }}$ World Congr. Genet. Appl. Livest. Prod. CD-ROM communication $\mathrm{N}^{\mathrm{o}}$. 18-01.

Meyer, K., 1992. Variance components due to direct and maternal effects for growth traits of Australian beef cattle. Livest. Prod. Sci. 31, 179-204.

Meyer, K., 1994. Estimates of direct and maternal correlations among growth traits in Australian beef cattle. Livest. Prod. Sci. 38, 91-105.

Meyer, K., 1997. Estimates of genetic parameters for weaning weight of beef cattle accounting for directmaternal environmental covariances. Livest. Prod. Sci. 52, 187-199.

Meyer, K., 2002. Estimates of covariance functions for growth of Australian beef cattle from a large set of field data. Proc. $7^{\text {th }}$ World Congr. Genet. Appl. Livest. Prod. CD-ROM communication $\mathrm{N}^{\mathrm{o}}$. 11.01.

Meyer, K., 2003. Estimates of variances due to sire x herd effects for weights of Hereford cattle. Proc. Assoc. Advmt. Anim. Breed. Genet. 15, 131-134.

Meyer, K. \& Hill, W.G., 1992. Approximation of sampling variances and confidence intervals for maximum likelihood estimates of variance components. J. Anim. Breed. Genet. 109, 264-280.

Mostert, B.E., Groeneveld, E., Rust, T. \& Van der Westhuizen, J., 1998. Multitrait variance component estimation of South African beef breeds for growth traits. Proc. $6^{\text {th }}$ World Congr. Genet. Appl. Livest. Prod. 23, 145-148.

Neser, F.W.C., Konstantinov, K.V. \& Erasmus, G.J., 1996. The inclusion of herd-year-season by sire interaction in the estimation of genetic parameters in Bonsmara cattle. S. Afr. J. Anim. Sci. 26, 75-78.

Notter, D.R. \& Hohenboken, W.D., 1990. Industry breeding structures for effecting and evaluating genetic improvement. Proc. $4^{\text {th }}$ World Congr. Genet. Appl. Livest. Prod. 15, 347-356.

Pereira, M.C., Mercadante, M.E.Z., Razook, A.G., Figueiredo, L.A. \& Albuquerque, L.G., 2008. Results of 23 years of selection for post-weaning weight in a Caracu beef herd. S. Afr. J. Anim. Sci. 38, 136-144.

Robinson, D.L., 1994. Models which might explain negative correlations between direct and maternal genetic effects. Proc. $5^{\text {th }}$ World Congr. Genet. Appl. Livest. Prod. 18, 378-381.

Robinson, D.L., 1996. Models which might explain negative correlations between direct and maternal genetic effects. Livest. Prod. Sci. 45, 111-122.

Souza, J.C., Ramos, A.A., Silva, L.O.C., Euclides Filho, K., Alencar, M.M., Wechsler, F.S., Gadini, C.H. \& Van Vleck, L.D., 1998. Effect of genotype x environment interaction on weaning weight of Nellore calves raised in four different regions of Brazil. Proc. $6^{\text {th }}$ World Congr. Genet. Appl. Livest. Prod. 23, 193-196.

Vercoe, J.E. \& Frisch, J.E., 1992. Genotype (breed) and environment interaction with particular reference to cattle in the tropics: Review. Aust. J. Anim. Sci. 5, 401-409. 